1. Mohammad Ehsanul Kabir (Corresponding Author)

PhD Candidate

School of Environment and Science

Griffith University

Room 0.36A, N13

170 Kessels Road, Nathan

Brisbane, QLD 4111, Australia

Mob: +61470313046

Email: ehsanul.kabir@griffithuni.edu.au

\title{
2. Dr Silvia Serrao-Neumann
}

Senior Lecturer

School of Social Sciences

Faculty of Arts and Social Sciences

University of Waikato

Hamilton 3240, New Zealand

Email: s.neumann@waikato.ac.nz

\section{Dr Peter Davey}

Senior Lecturer

School of Environment and Science

Griffith University

170 Kessels Road, Nathan

Brisbane, QLD 4111, Australia

Email: peter.davey@griffith.edu.au

\section{Dr Moazzem Hossain}

Associate Professor Adj

Department of International Business and Asian Studies

Griffith Business School

Griffith University, Nathan Campus

Brisbane, Australia

Email: m.hossain@ griffith.edu.au 
5. Md. Touhidul Alam

\title{
ACCEPTED MANUSCRIPT
}

Assistant Professor

Dhaka School of Economics

A constituent institution of the University of Dhaka

4/C Eskaton Garden Road

Dhaka 1000, Bangladesh

Email: touhidul.alam@dsce.edu.bd

\begin{abstract}
:
This paper examines the association between slow-onset natural hazards and the temporal aspects of human mobility - that is, short-term and long-term internal migration in the context of north-west Bangladesh. The paper contributes to the current understanding on the multiple stressors influencing individual's decisions to migrate from their rural origin, while examining the interplay between factors such as tipping points of migration (identified as drivers of migration), socio-demographic variables, and the contexts of slow-onset natural hazards. The analysis is based on empirical data relating to disadvantaged internal migrants or their household members living in drought-prone and riverine areas. A binary logistic regression model is used to analyse how various factors influence the temporality of migration. Key findings indicate that in the context of the natural hazards studied, financial stress at the household level and lack of economic resources are strongly associated with people's decisions to migrate for the-long or short-term. Based on such findings, the paper argues for diversified policy interventions for different groups of internal migrants in order to address difficulties associated with their mobility to and settlement at new locations.
\end{abstract}

Key words: vulnerability, tipping points, climate change adaptation, internal displacement, disaster and microfinance

\section{Introduction}

It is now widely recognized in academia and policy debates that climate change impacts are decreasing local livelihood options and increasing risks for vulnerable 
ACCEPTED MANUSCRIPT

populations in many places across the world, often driving them to migrate to other locations (Black et al., 2011; Lu et al., 2016; McLeman \& Smit, 2006). The issue of human migration is at the frontier of current research and policy discourses considering how climate change will differently affect countries across the world (Black et al., 2011; de Sherbinin et al., 2012; Foresight, 2011). In its Fifth Assessment Report, for the first time the International Panel on Climate Change (IPCC) has viewed human migration as both a consequence of and an adaptation response to climate change. The Report also linked climate change-influenced migration with issues relating to human security (Adger et al., 2015), urbanization challenges (Revi et al., 2014), emerging biophysical risks (Oppenheimer et al., 2014), and to multiple drivers of social vulnerability in rural areas (Dasgupta et al., 2014). The key message is that the increased exposure to environmental hazards and associated non-environmental challenges such as demographic and economic vulnerability are exacerbating involuntary migration in many climate-affected countries (Adger et al., 2015; de Sherbinin et al., 2012).

Nevertheless, understanding the complex interaction between the multiple drivers (including economic, environmental, social, and demographic) of migration in different hazard contexts remains a major challenge (Dasgupta et al., 2014). Moreover, the recent understanding of human mobility identifies it as a complex process involving both spatial and temporal aspects (Piguet, 2011). While a growing body of literature examines and tracks the spatial, or geographical, aspects of human mobility (such as Lu et al., 2016), fewer investigations have considered its temporal dimensions, such as long-term and short-term migration trends (Füssel, 2014). Further, available information on how certain hazard contexts may influence temporary (short-term) or permanent (mostly long-term) migration, or population displacement, is inconclusive (Piguet, 2011). Therefore, more studies are required to adequately develop policies to address the challenges of contemporary migration (Piguet et al., 2011). This paper aims to contribute to this understanding by investigating how slow-onset natural hazard contexts are associated with the temporal aspects of mobility-that is, short-term and long-term migration in north-west Bangladesh.

To this end, the paper draws on empirical data to identify and investigate the key drivers of migration associated with short-term and long-term migration in the context of north-west rural Bangladesh. The paper applies binary logistic regression modelling to explore the relationship between the temporal dimensions of migration outcomes as dependent variables while considering a range of drivers of migration as independent 
variables at the household level. Moreover, some common variables used in demographic research (including age, sex, and educational attainment, among others) are also considered as independent variables. Data were collected from two adjacent slow-onset hazard contexts: a drought-prone area, and a riverbank erosion-prone area in north-west Bangladesh.

The paper is structured as follows. It first provides a short literature review on the temporal dimensions of migration associated with slow-onset hazards. Then it briefly presents the two study contexts vulnerable to seasonal drought and riverbank erosion in north-west Bangladesh. The methods section describes the sampling, data collection, and data screening procedures. The results section presents key findings from the quantitative modelling. Based on key findings, the paper explores possible policy implications to address the temporal aspects of migration associated with slowonset hazard contexts.

\section{Temporal dimensions of internal migration}

A theoretical and empirical interest has emerged in understanding international migration involving migrants' temporal journey and limitation of legal status from arrival to citizenship or assimilation in a foreign country (Collins, 2012; Griffiths, Rogers, \& Anderson, 2013; Meeus, 2012). However, there is a gap in capturing the dynamic temporalities of internal migration within a particular country. Moreover, there is a limited number of in-depth studies exploring the linkages between the complexity of the hazard types and the temporal pattern of human mobility, such as migration for various time lengths as a coping mechanism for specific natural hazards (Piguet et al., 2010).

Firstly, it is important to disentangle the different types of environmentally influenced mobility to understand the impacts of climate change on the patterns of human migration (Piguet, 2011). In particular, it is critical to acknowledge the temporal dimension of migration. The United Nations (1998) systematically differentiates between human mobility as temporary displacements (those who are displaced for less than three months) that can lead to short-term migration (between three months and one year) or to long-term migration (more than one year). Other temporal dimensions of migration can be described as seasonal, recurrent, continuous, and permanent (McLeman, 2014). In most cases, researchers have defined those terms based on the migrants' reported duration of stay, observed behaviour, or the visa period granted to stay in foreign countries (Füssell, 2014). Other authors (Black et al., 2011; Hunter 
2006) argued that many of the recent trends of temporary and short-term migration are possibly associated with some specific features of environmental challenges. Hence, the various time lengths of stay during or after migration can be linked with slow-onset or rapid-onset types of natural hazards. It is argued that rapid-onset natural hazards, such as tropical cyclones, storms and tsunami can trigger mass temporary (or longterm) displacement (IOM, 2007). Conversely, other studies (Hauer, 2017; Mueller, Gray, \& Kose, 2014) provided new insights claiming that slow-onset hazards, such as drought, soil degradation and sea level rise can be also associated with a household's decision for long-term migration. However, drought has also been repeatedly linked with short-term migration behaviour because households take the decision to migrate as a livelihood diversification strategy (Kniveton, Schmidt-Verkerk, Smith, \& Black, 2008). Both arguments are far from reaching consensus, and the latter argument requires more systematic and follow-up investigations (Piguet, 2011).

Secondly, it is difficult to capture the complete set of factors influencing a household's decision to migrate. Various studies attempted to identify drivers, indicators, or determinants of migration by introducing a range of economic, demographic and environmental variables (de Sherbinin, 2012). These studies primarily focus on the social dimension of vulnerability while considering environmental exposure as a contextual factor. Typically, recent migration research has attempted to capture human mobility through representative household surveys (Black et al., 2013; Bohra-Mishra et al., 2014; Gemenne, 2011), case studies (Kartiki, 2011), and fewer longitudinal studies (Gray \& Muller, 2012). However, such studies face both methodological and conceptual difficulties in data collection (Lu et al., 2016). Methodological challenges involve gathering representative household surveys from climate-affected areas while considering households' places of origin, because migrant populations are geographically scattered in many hazardous locations (Füssell, 2014). Additionally, migration decisions as a response to climate and other risks are highly context-specific and can vary across regions (Black et al., 2011). Hence, there continues to be a need to better understand the significant factors (environmental, nonenvironmental, or both) influencing individual's and households' decision to migrate across different hazard contexts (Gray \& Muller, 2012). Moreover, existing economic, structural and environmental theories can only partially provide explanations of initiation of internal migration or the factors influencing its perpetuation (Füssell, 2014). However, much work remains to be done to develop a complete understanding of why 
ACCEPTED MANUSCRIPT

a temporal dimension of migration grows or declines within a context (Füssell, 2012). Overall, the research on environmentally driven internal migration has generally been hampered by, inter alia, the lack of empirical evidence of the factors influencing temporal dimensions of migration (Füssell, 2014).

Thirdly, possible interventions in government and non-government spheres involving migration issues impose further challenges relating to funding allocation and intervention schemes at different vulnerable locations (Piguet, 2011). Indeed, the longstanding debate on the extent to which migration should be considered as a failure to locally adapt or as an adaptation option to climate change influences national policies in the context of many low-income countries (Gemenne, 2013). The previous stance of the debate emphasises that people who migrate due to environmental reasons are induced by the ultimate failure to locally adapt to climate change impacts (German Advisory Council on Global Change, 2008; Global Humanitarian Forum, 2009). Hence, its advocates argue for reinforcing policy interventions to encourage vulnerable groups to stay at their places of origin. From this point of view, migration should be the last option, especially in the context of climate change. In contrast, many environmental scholars (Gemenne, 2013; Warner, 2009) argued that, historically, migration is a coping mechanism for many worldwide communities. Thus, people's migration behaviour should not only be explained in terms of a reactive strategy, but also as a proactive strategy to cope with climatic stimuli. Interestingly, both seasonal and shortterm migration are considered as a coping strategy in some recent studies (Rademacher-Schulz, Schraven, \& Mahama, 2014) where one or a few members of a family migrate for a short-term to support other household members to stay at their place of origin. However, the burning question remains as to whether the best solution is to help potential migrants to stay and locally adapt to the changing environment, or to focus on resettlement schemes (López-Carr \& Marter-Kenyon, 2015). We argue that this question cannot be answered without understanding the context of natural hazards and its interplay with the temporality of human mobility; namely, short-term and longterm migration behaviours and their drivers.

\subsection{The need to understand how slow-onset hazards influence migration}

A growing body of literature is examining both the causes of migration and the groups most vulnerable to migration (Gray, 2014; Füssel, 2014). This includes a series of studies on the demographic effect of hurricanes in the global North (Füssell et al., 
2010; Groen \& Polivka, 2010; Smith and McCarty, 2009); the impacts of drought in the global South (Barrios, Bertinelli, \& Strobl, 2006; Gray \& Muller, 2012); and the mass displacement incidents in the aftermath of earthquakes, tsunami and cyclones in Haiti, El Salvador, Pakistan, Bangladesh, and other Asian countries (Doocy et al., 2013; Sami et al., 2009). Many of these studies also analysed the number of people displaced, their demographic features, and the duration of stay away from their original place of residence (Füssell et al., 2010; Groen \& Polivka, 2010). One common argument is that the increased magnitude and frequency of some rapid-onset natural hazards will considerably exacerbate involuntary, long-term human migration (Christian Aid, 2007; IOM, 2008; IPCC, 2007; Myers, 2002). Additionally, follow-up studies on Hurricane Katrina and the Indian Ocean Tsunami also illustrated that temporary displacement due to rapid-onset natural hazards ultimately influences disadvantaged people's decisions to migrate for a long-term, or permanently (Fernando et al., 2010).

However, contemporary human mobility is a complex process, and migration dynamics as a response to environmental factors cannot be generalized without indepth knowledge of the different socio-environmental contexts of natural hazards (Piguet, 2011; Piguet et al., 2010). Gray and Muller (2012) argued that policymakers and academics oversimplify human mobility when assuming that rapid-onset hazards are more likely to trigger long-term migration. The authors used longitudinal survey data from rural Bangladesh to investigate the consequences of climate-related natural hazards for long-term population mobility (Gray \& Muller, 2012). Their results indicate that flooding has modest effects on long-term mobility, whereas other slow-onset hazards such as drought are more likely to have a stronger effect on long-term internal migration (Gray \& Muller, 2012). However, few follow-up studies have been conducted to further support the second hypothesis (Füssell et al., 2014). Moreover, Gray and Muller's (2012) study showed that in Bangladeshi sub-districts with a higher rate of crop failure, households with higher per capita expenditure are more likely to migrate compared with those with relatively lower per capita income. Earlier, other scholars (Afsar, 2000, 2003; Khandker, 2012; Qin, 2010) argued that most of the internal migration in Bangladesh may involve internal, short-distance and seasonal mobility as a form of livelihood diversification or climate adaptation. Hence, more studies are needed to further examine the temporality of migration in association with the context of different slow-onset hazards (Gray \& Muller, 2012). 
Specifically, further empirical research investigating questions relating to hazard contexts and the drivers of migration can improve our understanding of the patterns of future migration in different regions (Brown, 2008; Jager et al., 2007). Typically, policymakers, academics and practitioners tend to focus on human migration as being a result of rapid-onset environmental hazards. In particular, there is a trend towards reactive policy responses to rapid-onset hazards, including the development of building resilience after the Asian Tsunami (Suppasri et al., 2015), a series of studies after Hurricane Katrina (see Waters, 2016), and enhanced preparedness for tropical cyclones in Bangladesh (Ahmed, Kelman, \& Saha, 2016). However, the 'silent crises' fuelled by gradual environmental changes that may potentially compel a larger population to leave their home for various unknown durations (possibly involving shortterm and long-term migration) have received much less attention in policymaking (Peguet, 2011). Therefore, two overarching questions remain: (1) What are the factors influencing the temporality (long-term and short-term) of internal migration involving socio-economically disadvantaged people living in areas vulnerable to slow-onset hazards?; and (2) What factors are likely to have significant influence on people's decisions to migrate internally due to a particular context of slow-onset hazards? (Gray \& Muller, 2012; Piguet, 2011). At present, many studies have focused on the global South, especially in the context of the gradual decline of ecosystem services in subSaharan Africa (Füssel, 2014). This paper contributes to increasing this understanding by comparing factors influencing long-term and short-term migration in north-west rural Bangladesh.

\section{Research approach}

\subsection{Description of the study area}

Two different slow-onset natural hazard contexts in north-west Bangladesh were chosen for this study: an area vulnerable to seasonal drought, and an area vulnerable to riverbank erosion. The north-west part of Bangladesh has historically been designated as a drought-prone region. The region has a distinctive physiographic unit comprising a series of large blocks of terraced highland covering about 8,720 square kilometres (known as highland Barind Track) between the lowland floodplains of two major rivers, locally known as the Padma and Jamuna Rivers (Riches et al., 2008) (see Fig. 1). The region's average temperature ranges from $25^{\circ} \mathrm{C}$ to $35^{\circ} \mathrm{C}$ in summer; however, the highest temperature may reach $45^{\circ} \mathrm{C}$, or higher, particularly in the 
Rajshahi district (MoEF, 2013). In the north-west drought-prone areas, ground water recharge mainly depends on seasonal rainfall (Banglapedia, 2014).

Many lowland areas of north-west Bangladesh are vulnerable to riverbank erosion. The lowland floodplains are continuously shaped by the deltaic deposits of the two large and extremely dynamic rivers, creating many fluvial landforms or islands in the northern part of the country. According to the Bangladesh Water Development Board (BWDB), every year over one million people are directly affected by riverbank erosion, whereas about 25,000 people become internally displaced due to riverbank erosion along the Jamuna and Padma Rivers.

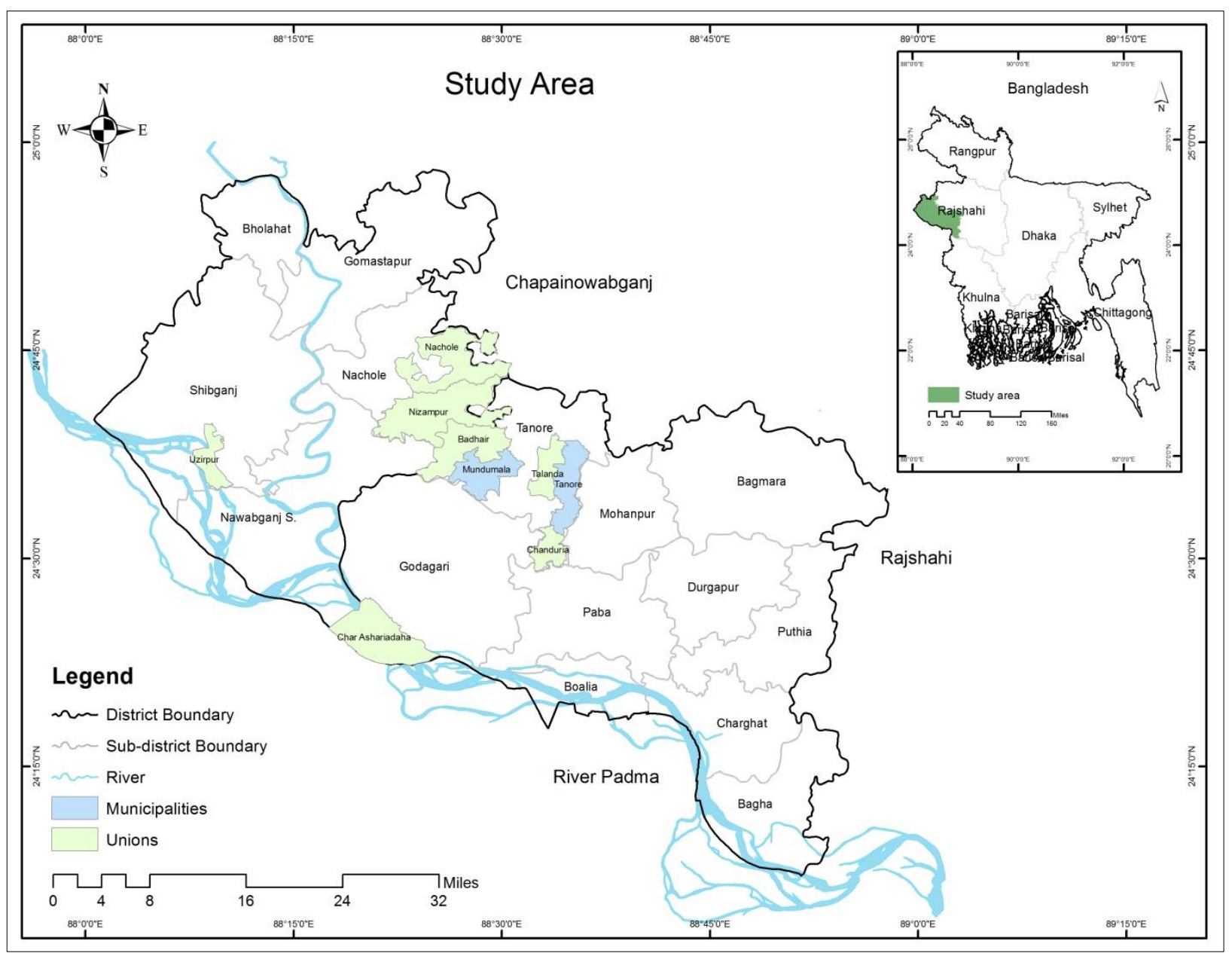

Figure 1. Map of Bangladesh showing study locations shaded in light green and blue

The study area covers four locations, classified as sub-districts, from two adjacent districts; namely, Rajshahi and Chapainawabganj in north-west Bangladesh. Firstly, in the Rajshahi district, Tanore and Godagari sub-districts are considered hotspots for slow-onset hazards. The Tanore sub-district is ranked as the district most 
vulnerable to drought (MoEF, 2013), whereas the Godagari sub-district is vulnerable to riverbank erosion (Karim, 2014). Second, in the Chapainawabganj district, Nachole and Shibganj sub-districts have been selected as hotspots for similar slow-onset hazards. The Nachole sub-district is listed as highly vulnerable to seasonal drought (MoEF, 2013), and the Shibganj sub-district is regarded as having a historical trend of riverbank erosion (Martin et al., 2014; Siddiqui \& Billah, 2014). Local government administration in each of these sub-districts is divided into several Unions ${ }^{1}$ and municipalities. Hence, each of the four sub-districts comprises a list of Unions and municipalities (municipalities only in urban areas).

\subsection{Data collection and analysis}

\subsubsection{Data collection}

Data collection involved two stages. In the first stage, consultation with 14 key informants was carried out to identify locations within the four selected sub-districts most vulnerable to drought and riverbank erosion. These key informants included individuals considered to have in-depth knowledge about the study locations-two Additional Deputy Commissioners (ADCs) at the district government level (one from each of the districts studied), four local government representatives at the sub-district level (one from each of the sub-districts), and eight local non-government organisation (NGO) representatives (two from each of the selected sub-districts). Based on their recommendations, seven Unions and two municipalities were shortlisted for this study (illustrated in Fig.1).

The second stage involved the identification of migrant households scattered in many parts of villages in the study area (in Unions and municipalities). At least four villages in each of the shortlisted Unions and municipalities were then visited to explore the individual cases of out-migration. Households were initially identified with the help of key informants and other local contacts. The identified household members were also asked whether they knew other households of out-migrants within the same village or community. Thus, with the help of some of the participants, other cases of outmigration were traced within the same village or community. Hence, the research partly

\footnotetext{
${ }^{1}$ The area within each sub-district (except for those in metropolitan areas) is divided into several Unions. Each of the Unions comprise multiple villages. Direct elections are held for each of the Unions to choose local government representatives, as per the nation's Local Government Act, No. 20, 1997.
} 
ACCEPTED MANUSCRIPT

relied on snowballing ${ }^{2}$ (or chain-referral) to increase the possibility of finding more cases of internal migration for the study interviews.

In total, 75 cases of internal (outbound) migrants were identified; 48 interviews were carried out in the selected drought-prone highland areas and 27 interviews in the riverine (lowland, riverbank erosion-prone) areas. Interviewees were migrants (persons who migrated, leaving their family at home, hence occasionally also found at home) or an adult family member (mainly spouse or parent of migrant) present at each of the selected households. The relatively small number of informants $(N=75)$ limits the generalization of the study's findings to other locations within Bangladesh and elsewhere. However, the empirical data provided in-depth insights about the drivers that influence short- and long-term migration that are useful for tailoring specific policies for assisting current and future first-time migrants. Following the United Nations guidelines (1998), long-term migrants identified by other family members comprised individuals who migrated from their habitual residence and stayed in another district or sub-district of Bangladesh for a minimum of one year, from the time of this study's data collection. Self-identified short-term migrants (persons present at study locations), or persons identified by their family members, comprised individuals who migrated to other sub-districts or districts (from their habitual residence) and continued to stay there for at least three months but less than a year, each time (United Nations, 1998). A summary of the study participants is presented in Table 1.

Table 1. Summary of the study participants.

\begin{tabular}{|c|c|c|c|c|c|c|c|}
\hline District & Sub-district & $\begin{array}{l}\text { Type of } \\
\text { hazard }\end{array}$ & Male & Female & $\begin{array}{l}\text { Short-term } \\
\text { migrants/family } \\
\text { members }\end{array}$ & $\begin{array}{l}\text { Family } \\
\text { members of } \\
\text { long-term } \\
\text { migrants }\end{array}$ & Total \\
\hline Rajshahi & $\begin{array}{l}\text { Tanore sub- } \\
\text { district }\end{array}$ & $\begin{array}{l}\text { Seasonal } \\
\text { drought }\end{array}$ & 19 & 7 & 8 & 18 & 26 \\
\hline Chapainawabganj & $\begin{array}{l}\text { Nachole sub- } \\
\text { district }\end{array}$ & $\begin{array}{l}\text { Seasonal } \\
\text { drought }\end{array}$ & 15 & 7 & 7 & 15 & 22 \\
\hline Rajshahi & $\begin{array}{l}\text { Godagari } \\
\text { sub-district }\end{array}$ & $\begin{array}{l}\text { Riverbank } \\
\text { erosion }\end{array}$ & 15 & 0 & 12 & 3 & 15 \\
\hline \multirow[t]{2}{*}{ Chapainawabganj } & $\begin{array}{l}\text { Shibganj } \\
\text { sub-district }\end{array}$ & $\begin{array}{l}\text { Riverbank } \\
\text { erosion }\end{array}$ & 12 & 0 & 12 & 0 & 12 \\
\hline & & & & & $=39$ & $n=36$ & $N=75$ \\
\hline
\end{tabular}

The structured interview comprised both closed and open-ended questions. Interviews inquired about the migration drivers (described as a specific, critical situation

\footnotetext{
${ }^{2}$ In social science research, snowball sampling, or chain-referral sampling, is a non-probability sampling technique where existing study respondents identify or recruit future respondents from among their contacts (Babbie, 2011).
} 
by each of the participants) that were strongly associated with the individual's or family's migration tipping points (after which a decision to migrate became inevitable). Interview data were complemented by field notes taken at the same time and after the conduct of interviews. In circumstances where the participants were not able to refer to or recall any practical issue or reason associated with the migration decision, a probing $^{3}$ or prompting technique was used to assist them to add any issue they thought was important. The interviews also captured socio-demographic data, such as age, educational attainment, and monthly expenditure of the migrants, among others.

\subsubsection{Data analysis}

Data analysis adopted a mixed-method approach using both qualitative and quantitative techniques. Firstly, a qualitative analysis of interview transcripts was carried out, followed by an open coding technique. All interview transcripts were reviewed multiple times, and qualitative data were segmented into meaningful concepts and described in codes, which were initially short sequences of words (Blair, 2015). A codebook was developed and updated multiple times to advance data analysis (Saldana, 2016). Similar coded segments were then grouped to develop a list of code categories, where each of the categories represented one driver influencing the migration decision. In general, the participants recognised these drivers as situations of impending threat to the wellbeing of their households that motivated their final decision to migrate. Each of the participants reported one driver that tipped their migration decision. A total of seven key drivers of migration (which functioned as tipping points of migration) were identified and considered as independent variables for the quantitative analysis. These were credit burden, seasonal income poverty, income poverty, loss in agriculture, lack of jobs for women, loss in small business, and personal reasons. Brief explanations for each of these drivers are presented in Table 2.

Moreover, this study also considered common factors typically used in demographic research as independent variables. Analysing these factors along with the participants' self-reported drivers (or tipping points) of migration extended the scope for interpreting the complex presence of multiple stressors in migration decision. The selected factors were (1) Age: age of migrant; (2) Sex: sex of migrant; (3) Educational attainment: years of schooling; (4) Expenditure per month: household expenditure per month; (5) Household $(\mathrm{HH})$ size: number of members in each household; (6) Land

\footnotetext{
${ }^{3}$ In qualitative study, probing technique refers to stimulating an informant to produce more information (Babbie, 2011).
} 


\section{ACCEPTED MANUSCRIPT}

holding: Three different types of land holding were noticed-Own, Khas, and Rented ('Own' for land ownership, 'Khas' for government-owned fallow land, and 'Rented' for rented accommodation for landless families); (7) Credit receiver: household owing money to other individuals or institutions. Additionally, this study considered 'coping strategy' in the list of independent variables, which refers to the existing coping strategy (if any) at the household level to manage hazard events.

Secondly, a quantitative analysis using binary logistic regression was carried out to investigate the association between all independent variables (both the reported drivers of migration and demographic variables) and temporality of migration (short-term and long-term migration). This is a multivariate statistical method useful for analysing the relationship between one binary dependent variable and one or more nominal-, ordinal, interval-, or ratio-level independent variables (Kleinbaum \& Klein, 2010). As the study involved both dummy (also known as categorical) variables and continuous variables, the binary logistic regression was suitable for incorporating such relationships into a predictive model (Kleinbaum \& Klein, 2010; Meyers, Gamst, \& Guarino, 2013).

Table 2. Explanation of drivers that tipped migration.

\begin{tabular}{|l|l|}
\hline $\begin{array}{l}\text { Driver of } \\
\text { vulnerability that } \\
\text { tipped migration } \\
\text { decision }\end{array}$ & Explanation \\
\hline Microcredit burden & $\begin{array}{l}\text { Microcredit schemes in the mandate of rural poverty } \\
\text { alleviation are operated by non-government organisations } \\
\text { (NGOs) in the study areas. The disadvantaged rural people } \\
\text { often receive microcredit, which requires frequent } \\
\text { repayment instalments, either on a weekly or monthly basis. } \\
\text { The participants explained that 'microcredit burden' was } \\
\text { often accompanied by harassment by lending agencies, such } \\
\text { as the use of abusive language, exhibition of intimidating } \\
\text { behaviours, and seizure of property in the case of microcredit } \\
\text { default or when regular instalments of credit were not paid. }\end{array}$ \\
\hline $\begin{array}{l}\text { Seasonal income } \\
\text { poverty }\end{array}$ & $\begin{array}{l}\text { In the areas studied, every year adults experience } \\
\text { unemployment periods due to the seasonal nature of rural } \\
\text { occupations (such as farm labourer). An elevated level of } \\
\text { financial stress at the household level in seasonally lean } \\
\text { periods was viewed as the situation that tipped the migration } \\
\text { decisions for some participants. }\end{array}$ \\
\hline Income poverty & $\begin{array}{l}\text { Some of the areas studied lack year-round economic } \\
\text { activities and employment opportunities. The participants } \\
\text { described the situation of persistent income poverty as an } \\
\text { unbearable condition at the household level. }\end{array}$ \\
\hline Loss in agriculture & The participants involved in farming activities viewed \\
\hline
\end{tabular}




\begin{tabular}{|l|l|}
\hline $\begin{array}{l}\text { Driver of } \\
\text { vulnerability that } \\
\text { tipped migration } \\
\text { decision }\end{array}$ & Explanation \\
\hline & $\begin{array}{l}\text { financial loss in agriculture as a major driver that tipped their } \\
\text { decisions to migrate. Loss in agriculture was commonly } \\
\text { illustrated by situations whereby all or parts of the crops on a } \\
\text { farm were lost due to a failed harvest. }\end{array}$ \\
\hline $\begin{array}{l}\text { Lack of jobs for } \\
\text { women }\end{array}$ & $\begin{array}{l}\text { Women, especially in the absence of male wage earners in } \\
\text { the family, or during a serious illness of these earners, } \\
\text { experience a higher level of financial stress. The participants } \\
\text { also claimed a general lack of local employment } \\
\text { opportunities for female candidates. }\end{array}$ \\
\hline $\begin{array}{l}\text { Loss in small } \\
\text { business }\end{array}$ & $\begin{array}{l}\text { few participants of this study reported that a financial } \\
\text { tipped their migration decisions. After the financial loss, } \\
\text { increased financial hardship in the household influenced } \\
\text { them to migrate in search of alternative employment. }\end{array}$ \\
\hline Personal reasons & $\begin{array}{l}\text { Personal reasons to migrate are diverse, and a common } \\
\text { pattern was not found for this study. }\end{array}$ \\
\hline
\end{tabular}

In order to avoid multicollinearity and effects of overfitting models, two widely used model adequacy tests, chi-square test and $t$-test, were conducted, and only the shortlisted variables are presented in Table 3 (Hair et al., 2013). In order to select the most relevant variables as explanatory variables for the model, this study firstly initiated a univariate analysis, obtaining $p$-values from chi-square test specifically for all selected categorical variables (see Table 3), such as Land Holdings ("Own", "Khas" and "Rented"), Credit Receiver ("Yes" for household owing money to individual or institution and "No" when it is not applicable), Income Poverty ("Yes" for reported income poverty and "No" when it is not applicable), Seasonal Income Poverty ("Yes" for reported seasonal income poverty and "No" when it is not applicable), Loss in Agriculture ("Yes" for reported loss in agriculture and "No" when it is not applicable) and last, Coping Strategy ("Yes" for having a household coping strategy and "No" when there is no coping strategy). Secondly, $\mathrm{p}$ - values were obtained from $t$-test specifically for continuous variables such as age, educational attainment, household expenditure per month, and household size (after Hosmer \& Lameshow, 2000). While shortlisting variables for a multivariate model, a $p$-value $<0.25$ was accepted as a screening criterion to avoid oversight of any important variable (Hosmer \& Lameshow, 2000). 
Table 3. Distribution of explanatory variables and their relevant significance.

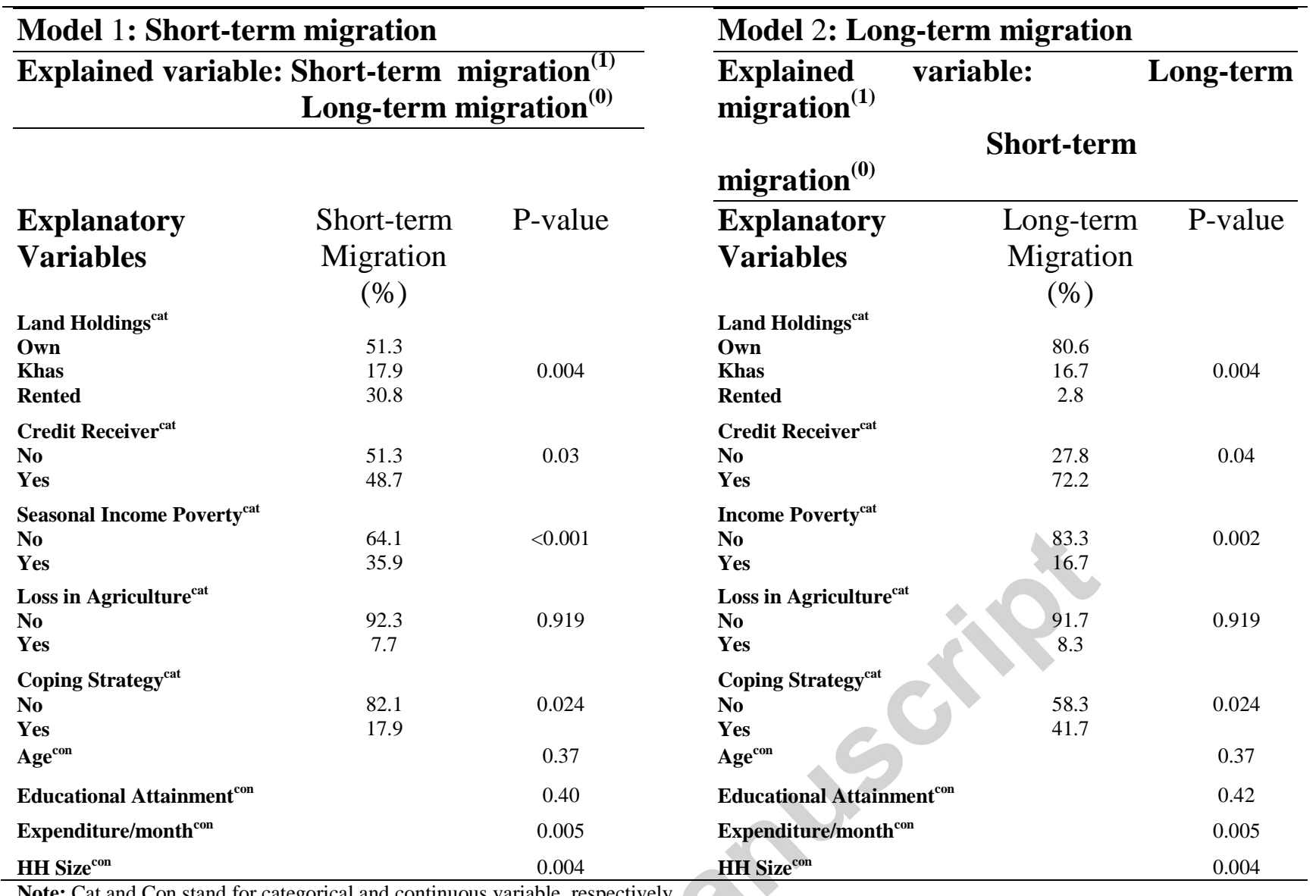

\section{Results}

Models 1 and 2 presented in Table 4 were estimated using maximum likelihood procedures. This requires the estimation of a single equation logistic regression model for each model with binary dependent variables. In each of the models, we considered two migration choices: for Model 1, $1=$ Short-term migration and $0=$ Long-term migration; and, for Model 2, 1 = Long-term migration and 0 = Short-term migration. To make the comparison easier, the results for both are presented in Table 4. Asterisks in Table 4 indicate the significance of each independent variable: $p$ values less than 0.01 are summarised with three asterisks, $p$ values less than 0.05 are summarised with two asterisks, and $p$ values less than 0.1 are summarised with one asterisk.

For most cases, the independent variables in Table 4 show an opposite sign (positive versus negative) for short-term and long-term migration decisions. For instance, a short-term migration decision was chosen by the individuals from landless households who resided on rented land (see Land Holdings), individuals with a larger number of members in the households (see HH Size), individuals who became subject 
to seasonal income poverty (see Seasonal Income Poverty), and individuals experiencing higher household expenditure per month (see Expenditure/month). On the other hand, none of these factors was positively associated with the households where adult individuals migrated for the long-term. It should also be noted that some other factors, such as coping strategy and credit receiver, were not significant in either cases.

During the model-building, no significant association between credit burden and the types of migration decision was found. However, the qualitative content analysis highlighted that credit burden was a frequently reported driver of internal migration decisions in some of the studied Unions and municipalities. This finding required the resulting data to be further analysed and interpreted in relation to the assumptions by which they were generated. Hence, the study added an interaction effect between location and credit burden to explore whether any association existed between the locations (drought-prone and riverbank erosion-prone areas) and credit burden. Furthermore, the application of the term interaction is aligned with the research objective of this study; that is, investigating whether there is a relationship between the slow-onset hazard contexts and the temporality of migration.

Table 4. Results from multivariate logistic regression models.

\section{Model 1: Short-term migration Explained variable: Short-term migration ${ }^{(1)}$ \\ Long-term migration ${ }^{(0)}$}

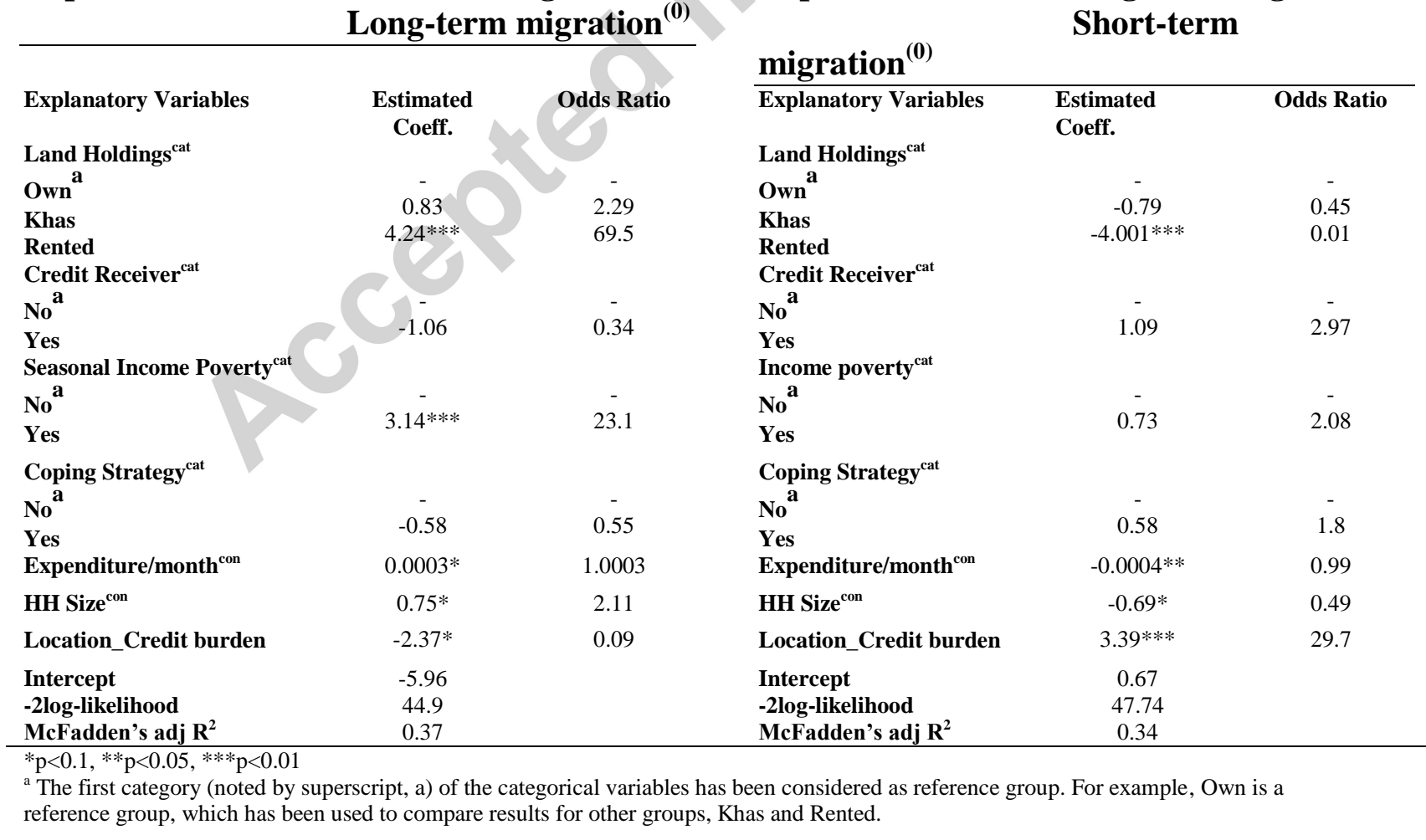

Model 2: Long-term migration

Explained variable: Long-term migration ${ }^{(1)}$ Short-term 
As shown in Table 4, interaction between location and credit burden was found to be negatively significant in the case of short-term migration. The results showed that individuals with credit burden living in the drought-prone areas were less likely to migrate for the short-term compared with the rest of the people studied. However, interaction between location and credit burden was found as highly significant in Model 2 , which indicates that individuals with credit burden in the drought-prone areas are highly likely to migrate for the long-term compared with the rest of the people studied, such as households without credit burden in highland areas, households with credit burden in lowland areas, and households without credit burden in lowland areas.

\subsection{Testing of accuracy: Receiver Operating Characteristic}

To evaluate the extent to what results from the fitted binary logistic regression models were valid, receiver operating characteristic (ROC) curves were used. Figure 2 reveals that the area under the curve is 0.943 for Model 1, and the area under the curve is 0.935 for Model 2. According to the grading guidelines by Kleinbaum and Klein (2010) (where a value of 0 indicates a perfectly inaccurate test and a value of 1 reflects a perfectly accurate test), both fitted models can be considered as excellently discriminating and highly significant.

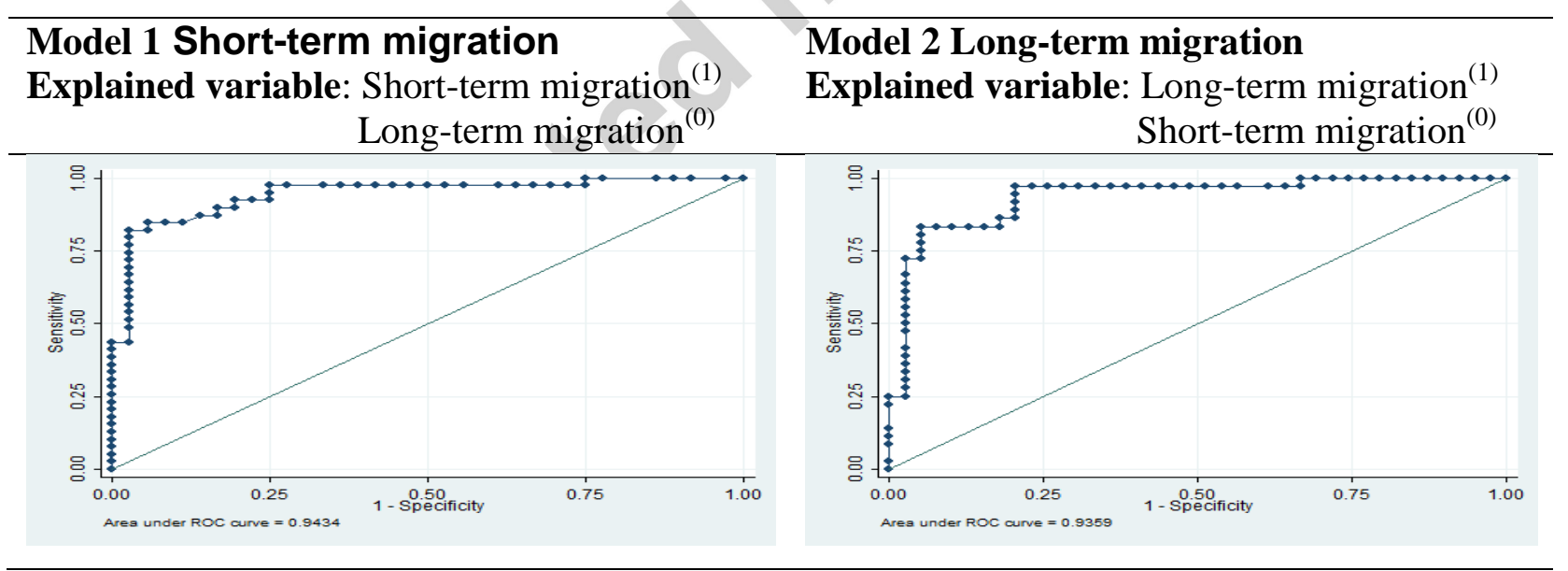

Figure 2. Receiver operating characteristic curves (for Model 1 and Model 2). 


\section{Discussion}

\section{ACCEPTED MANUSCRIPT}

The possible linkage between climate and migration has long been examined in academic and policy discourses (Stern, 2007; Warner, 2010). Recent studies (Laczko \& Aghazarm, 2009; Scheffran et al., 2012; Stojanov et al., 2017; Tacoli, 2009) emphasised that migration is a potential adaptation strategy used to cope with the current changes in climate and environment. Environmental drivers such as heat stress can impact agricultural productivity and so increase household expenditure due to destabilised prices for food and other necessities (Porter et al., 2014). As a response, migration can potentially generate alternative livelihood options for individuals who are affected by such impacts (Klaiber, 2014). Patnaik and Narayanan (2015) noticed that remittances sent by migrants to non-migrant family members in rural India helped to reduce financial shocks generated by drought and thus strengthened the adaptive capacity of the home region. In Bangladesh, migration not only occurs in a wider context of livelihood diversification needs and local unemployment situations but also functions as an autonomous strategy for climate change adaptation (Stojanov et al., 2016). The country's climate-centric economic activity (where agriculture is the major employment source) is facing greater risk and uncertainty than before and often results in lack of food security and loss of rural livelihoods. Both lower daily income and an increased household expenditure on food influence short-term rural-urban migration from northern Bangladesh (Ahamad et al., 2011). Khandker et al. (2012) also found that the lack of seasonal employment and the higher number of members per household are associated with the increased probability of seasonal migration from north-west rural Bangladesh. The current study offers additional empirical evidence aligned with these views and argues that short-term migration has the potential to minimise households' financial burden, especially during seasonal lean periods. In particular, this study demonstrated that the economic factors, namely, seasonal income poverty, increased household expenditure (per month), higher numbers of family members (per household), and lack of land entitlement significantly influenced individuals' short-term migration decisions in the overall study areas (see Table 4). However, considering the population numbers in Bangladesh and the studied region, more extensive data collection is required to provide a more accurate picture of the migration factors. 
Concerning long-term migration, the results indicated that the pressure of institutional microcredit repayments was a highly significant driver for internal migration decisions only in the drought-prone areas. Indeed, during the interviews, many participants alleged that they were harassed by microcredit staff regarding credit default, which aggravated their financial and social stress (e.g., embarrassment in the neighbourhood) and gradually forced them to flee or migrate for the long-term. Bylander $(2014,2015)$ also observed that in rural Cambodia where institutional microfinance schemes usually fulfil the poor households' immediate consumption needs, but in the long run the burden of high instalment rates drives household members to migrate for waged employment. These people tend not to return home unless their debts are paid. Nonetheless, the qualitative findings from this study indicated that the participants in the riverine areas do not even have access to institutional microcredit. This lack of access to institutional microcredit is possibly the reason as to why no positive association was found between credit burden and temporality of migration decisions in the riverine areas (see Table 4). Hence, findings from both qualitative and quantitate analyses are also consistent with each other.

Overall, the association between microcredit burden and long-term migration in the studied drought-prone locations highlighted the important ways in which the local socio-economic context-and not only biophysical hazards-can influence migration decisions. Such a linkage also poses both conceptual and practical questions across the field of hazard-migration research and the role of microfinance as a rural development strategy. Firstly, many hazard-migration studies emphasised environmental drivers often without a deeper understanding of the social or institutional contexts and local interventions. For example, certain types of natural hazards are often identified as providing either long-term or short-term migration stimuli (Hauer, Evans, \& Mishra, 2016; IDMC, 2014) regardless of the adaptation or mal-adaptation interventions at the local level. Climatic variables, such as precipitation and temperature, may become statistically significant predictive factors influencing a migration decision; however, estimating a model without the economic and sociodemographic factors of a specific location or hazard context may obscure many important contextual situations (O'Loughlin et al., 2012). Although some scholars have recognised that human-environment relationships are highly context-specific, much empirical work is needed to theorize the various contexts and factors leading to migration (Gray \& Wis, 2016). As Gray and Wis (2016) pointed out, the lack of attention 
to the context of climate/environment-induced migration typically assumes that some climatic stressors mono-causally result in permanent and long-distance migration and, thus, artificially separate the drivers of migration from the socio-economic reality within which the migration is likely to take place. This study concurs with this argument while examining two slow-onset hazard contexts, and by identifying that microcredit debt/burden was a stronger driver for long-term migration or displacement in the drought-prone locations but not in the riverine area. This finding offers critical insights into what the context of climate/environment-induced migration means by illustrating how vulnerable populations link socio-economic pressures with slow-onset hazards in rural Bangladesh.

Secondly, development interventions such as microfinance schemes are often viewed as positive stimuli towards hazard-climate adaptation (Hammill, Matthew, \& McCarter, 2008; Shardul \& Carraro, 2010). The increased access to institutional microfinance is also deemed as an enabling factor that attenuates the climate change drivers in the rural context (Chirambo, 2017; Hammill et al., 2008). However, some studies (Angelucci et al., 2013; Chowdhury, 2009) argued that institutional microfinance is not a cure-all remedy for rural poverty. Relatively vulnerable groups, such as landless people and unemployed widows, are less successful in microcredit repayment compared to borrowers who already have some assets (Chowdhury, 2009; Jain, 2003). This study confirms these findings and argues that rural development and climate adaptation policies in general, and microfinance intervention specifically, need to take into account the specific socio-environmental constraints affecting particular locations for it to be effective. In their everyday struggles, the disadvantaged rural participants in the studied drought-prone areas tended to access microcredit institutions as part of their initial coping strategy, which in the long run often resulted in increased external pressure beyond their control (e.g., alleged harassment by microcredit staff) and influenced their decision to leave their community. In contrast, people in the studied riverine locations had lower access to institutional microcredit. In summary, although borrowing microcredit was possibly used as a short-term coping strategy by the disadvantaged rural people in the drought-prone locations, the empirical evidence showed that in the long run it can instead increase their existing or create new vulnerability, and may not serve the poorest of the poor (e.g., people living in remote riverine locations). 
Furthermore, Kabir et al. (2018) recently argued that the conflicts involved in microcredit recovery was one of the drivers of long-term migration in Bangladesh's drought-prone areas. Conversely, in comparing locations subject to different slow-onset hazards this study showed that when access to rural microcredit was significantly low (e.g., lowland locations had limited access to microcredit compared to highland locations), other economic issues such as seasonal income poverty, lack of land entitlement, household size, and increased household expenditure strongly influenced individuals' decisions to migrate for a short-term. This finding indicates that the existing practice of microcredit schemes in areas prone to slow-onset hazards may in fact be contributing to increasing future long-term rural-to-urban migration in Bangladesh. This finding calls for more detailed studies about the extent to which microcredit debts are driving long-term displacement from areas affected by slow-onset hazards.

\section{Conclusion and policy implications}

This study aimed to understand the association between various drivers of migration and the two temporal aspects of internal migration; namely, short-term and long-term. Two different slow-onset hazard contexts and their association with such temporalities were examined. The results and discussion sections demonstrated that for short-term migration, seasonal income poverty, household land ownership, household expenditure (per month), and size of households were significant drivers associated with an individual's decision to migrate internally. In contrast, household land holding, expenditure per month, seasonal income poverty, and size of households did not seemingly trigger individual's decisions to migrate for the long-term. Institutional microcredit burden had a moderate influence as a driver of long-term migration for the total sample of the study. However, when considering only the drought-prone locations, microcredit burden was found to have a much higher influence on individual's long-term migration decision. These findings indicated that the disadvantaged rural population of north-west rural Bangladesh may rely on short-term migration as a livelihood diversification strategy, especially in seasonal lean periods. Additionally, the study argued that microcredit was probably used to meet immediate consumption needs of the poor, or sometimes as a short-term coping strategy during economic and environmental shocks, which may initially delay the tipping point for long-term migration. However, in the drought prone locations, the study found that when 
ACCEPTED MANUSCRIPT

participants reached their threshold to deal with overdue microcredit burden, long-term migration became inevitable.

For policy interventions, this study suggested that it would be inappropriate to consider all types of internal migrants (i.e., long-term vs. short-term) under the same service scheme. For example, many of the short-term movements in Bangladesh are linked with seasonality and natural hazards and, when the expected income is earned, this group of migrants tends to return home on a more regular basis. Therefore, interventions should provide support to short-term migrants during their travel phase for more inexpensive and safer travel, and at their short-term destinations for more affordable and safer shelters, emergency medication, and vaccinations. Further assistance is required to help the short-term migrants link with potential work contractors and employers at destination points. Again, at these destinations, many of the long-term migrants may suffer from multiple financial burdens, such as pressure to send remittances to family members living at places of origin and the burden of unpaid microcredit instalments at their places of origin. Double financial burdens may also lead the disadvantaged migrants to compromise personal wellbeing and healthcare expenses, specifically when living in urban slums. Hence, policies that help this group of migrants to improve their dwelling, financial and health conditions, and that provide a safer means of sending remittances home, are needed. Where feasible, planned relocation initiatives will be nothing but part of adaptation action for such long-term internal migrants in Bangladesh.

Finally, as climate change is likely to exacerbate the occurrence of slow-onset natural hazards leading to both short- and long-term internal migration, migration needs to be treated as an effective climate change adaptation strategy, rather than as an undesirable outcome of climate change. Migration needs to be incorporated into the development of climate change adaptation initiatives to enable the allocation of services and establishment of safe support systems, especially in urban areas, industrial zones, and other potential destinations that attract internal migrants.

\section{References}

Adger, W. N., Arnell, N. W., Black, R., Dercon, S., Geddes, A. and Thomas, D. S. G., 2015. Focus on environmental risks and migration: causes and Consequences. Environ. Res. Lett. 10, 1-6.

Afsar, R., 2000. Rural urban migration in Bangladesh: causes, consequences and challenges. University Press Limited, Dhaka. 
Afsar, R., 2003. Internal migration and the development nexus: the case of Bangladesh, paper presented at the Regional Conference on Migration, Development and Pro-Poor Policy Choices in Asia, 22 - 24 June, Dhaka, Refugee and Migratory Movements Research Unit, Dhaka, and UK Department for International Development, London.

Ahmed, B., Kelman, I., Fehr, H. K. and Saha, M, 2016. Community Resilience to Cyclone Disasters in Coastal Bangladesh. Sustainability 8(8), 1-29, doi:10.3390/su8080805

Ahamad, M. G., Khondker, R. K., Ahmad, Z. U. and Tanin, F., 2011. Seasonal Unemployment and Voluntary Out-Migration from Northern Bangladesh. Modern Economy 2, 174-179 doi:10.4236/me.2011.22023 Published Online May 2011 http://www.SciRP.org/journal/me

Angelucci, M., Karlan, D. and Zinman, J., 2013. Microcredit Impacts: Evidence from a Randomized Microcredit Program Placement Experiment by Compartamos Banco. Retrieved on Aug 12016 from

http://www.dartmouth.edu/ jzinman/Papers/CompartamosImpact_Dec16_2013.pdf

Babbie, E. (2011) Social Research Methods. Wadsworth: USA

Banglapedia (National Encyclopaedia of Bangladesh), 2014. Barind Tract. National Encyclopaedia of Bangladesh. Retrieved on 1 Aug 2017 from http://en.banglapedia.org/index.php?title=Barind_Tract

Black, R., Dominic, K. and Schmidt-Verkerk, 2011. Migration and climate change: towards an integrated assessment of sensitivity. Environment and Planning 43, 431450.

Doi: $10.1068 / a 43154$.

Black, R., Kniveton, D., Schmidt-Verkerk, K., 2013. Migration and Climate Change: Toward an Integrated Assessment of Sensitivity. In Faist, T. and Schade, J., Editors, Disentangling Migration and Climate Change, pp. 29-53. Springer, USA.

Bohra-Mishra, P., Oppenheimer, M., Hsiang, S.M., 2014. Nonlinear permanent Migration response to climatic variations but minimal response to disasters. Proc. Natl.
Acad.
Sci.
111
(27),
9780-9785.

Barrios, S., Bertinelli, L., \& Strobl, E., 2006. Climatic change and rural-urban migration: The case of sub-Saharan Africa. Journal of Urban Economics (60), 357-371.

Brown O., 2008 The numbers game. Forced Migration Review, 31, 8-9

Bylander, M., 2014. Borrowing Across Borders: Migration and Microcredit in Rural Cambodia. Development and Change 45(2), 284-307. DOI: 10.1111/dech.12080

Bylander, M., 2015. Credit as Coping: Rethinking Microcredit in the Cambodian Context. Oxford Development Studies, 43(4): 533-553. https://doi.org/10.1080/13600818.2015.1064880

Chirambo, D., 2017. Enhancing Climate Change Resilience Through Microfinance: Redefining the Climate Finance Paradigm to Promote Inclusive Growth in Africa. Journal of Developing Societies 33(1).

Chowdhury, A., 2009. Microfinance as poverty reduction tool: a critical assessment. Economic and Social Affairs. DESA Working Paper No. 89. Retrieved on 15 Aug from http://www.un.org/esa/desa/papers 
MoEF (Ministry of Environment and Forest), 2013. Drought Vulnerability Ranking in Bangladesh. Comprehensive Disaster Management Program (CDMP). Ministry of Disaster and Relief. Retrieved on July 2015 from www.cdmp.org.bd

Christian Aid, 2007. Human Tide: The Real Migration Crisis. Christian Aid Report May. London.

Collins, F. L., 2012. Transnational Mobilities and Urban Spatialities: Notes from the Asia- Pacific. Progress in Human Geography 36(3), 316-35.

Dasgupta, P., Morton J. F., Dodman, D., Karapinar, B., Meza, F., Rivera-Ferre, M.G., Toure Sarr Aand Vincent, K.E., 2014. Rural areas Climate Change 2014: Impacts, Adaptation, and Vulnerability. Part A: Global and Sectoral Aspects.

Doocy, S., Dick, A., Daniels, A., Kirsch, T.D., 2013. The Human Impact of Tropical Cyclones: a Historical Review of Events 1980-2009 and Systematic Literature Review. PLOS Currents Disasters 1(0), doi: 10.1371/currents.dis.2664354a5571512063ed29d25ffbce74.

Foresight Migration and Environmental Change, 2011. Final Project Report of Foresight Migration and Environmental Change. London, The Government Office for Science.

Fernando, N., Warner, K. and Birkmann, J., 2010. Migration and Natural Hazards: Is Relocation a Secondary Disaster or an Opportunity for Vulnerability Reduction? In T. Afifi, J. Jager, Editors, Environment, Forced Migration and Social Vulnerability. DOI 10.1007/978-3-642-12416-7_11,_Springer-Verlag Berlin Heidelberg

Füssell, E., Hunter, L. M., Gray, C. L., 2014. Measuring the Environmental Dimensions of Human Migration: The Demographer's Toolkit. Glob Environ Change 28, 182-191. doi:10.1016/j.gloenvcha.2014.07.001.

Füssell, E., 2012. Space, time, and volition: Dimensions of migration theory. In: Rosenblum, M.R., Tichenor, D.J., Editors, The Oxford Handbook of the Politics of International Migration. Oxford University Press; New York.

Füssell, E., Sastry, N., and VanLandingham, M.,2010. Race, socioeconomic status, and return migration to New Orleans after Hurricane Katrina. Population and Environment 31(1-3), 20-42.

Groen, J., and Polivka, A., 2010. Going home after Hurricane Katrina: Determinants of return migration and changes in affected areas. Demography 47, 821-844.

Gemenne, F., 2011. Why the numbers don't add up: A review of estimates and Predictions of people displaced by environmental changes. Global Environ. Change 21, S41-S49.

Gemenne, F., 2013. Introduction: The State of Environmental Migration. Institute for Sustainable Development. International Relations (IDDRI) and International Organization for Migration (IOM).

German Advisory Council on Global Change (WBGU), 2008. Climate Change as a Security Risk. Earthscan, London.

Global Humanitarian Forum, 2009. The Anatomy of a Silent Crisis. Global Humanitarian Forum, Geneva.

Griffiths, M., Rogers, A. and Anderson, B., 2013, Migration, Time and Temporalities: Review and Prospect, COMPAS Research Resources Papers, Centre on Migration, Policy and Society, Oxford. Accessed on 18 December 2013 from: 
http://www.compas.ox.ac.uk/fileadmin/files/Publications/Research_Resources/ Citizenship/Report_-_Migration_Time_and Temporalities_FINAL.pdf.

Gray, C. L., Mueller, V., 2012. Natural disasters and population mobility in Bangladesh. Proc. Natl. Acad. Sci. 109, 6000-6005.

Gray, C., Frankenberg, E., Gillepsie, T., Sumantri, C., Thomas, D., 2014. Studying displacement after a disaster using large scale survey methods: Sumatra after the 2004 tsunami. Annals of the Association of American Geographers 104(3), 594612.10.1080/00045608.2014.892351 [PubMed:24839300]

Gray, C. and Wis, E., 2016. Country-specific effects of climate variability on human migration. Climatic Change 135, 555-568. DOI 10.1007/s10584-015-1592-y

Hair, J. F., Black, W. C., Babin, B. J. and Anderson, R. E., 2013. Multivariate Data Analysis, Pearson Education Limited, Australia.

Hammill, A., Matthew, R. and McCarter, E. (2008) Microfinance and Climate Change Adaptation, IDS Bulletin 39(4).

Hauer, M. E., Evans, J. A. and Mishra, D. R., 2016. Millions projected to be at risk from sea-level rise in the continental United States. Nature Climate Change 6, 691-695, doi:10.1038/nclimate2961

Hauer, M. E., 2017. Migration induced by sea-level rise could reshape the US population landscape. Nature Climate Change 7, 321-325. doi:10.1038/nclimate3271

Hosmer, D. W. and Lameshow, S., 2000. Applied Logistic Regression. New York: John Wiley \& Sons, Inc.

Hunter, L. M., 2006. Migration and Environmental Hazards. Popul Environ 26(4), 273302. doi: 10.1007/s11111-005-3343-x

IOM, 2007. Migration, Development and Natural Disasters: Insights from the

Indian Ocean Tsunami. IOM Migration Research Series. International Organization for Migration: Geneva

IOM. (2008). Migration and Climate Change, Report No. 31. International Organization for Migration, Geneva.

IPCC, 2007. Climate Change 2007: Impacts, Adaptation and Vulnerability. Contribution of Working Group II to the Fourth Assessment Report of the Intergovernmental Panel on Climate Change, M.L. Parry, O.F. Canziani, J.P. Palutikof, P.J. van der Linden and C.E. Hanson, Eds., Cambridge University Press, Cambridge, UK, 976pp

Jäger, J., M.T.J. Kok, J.C. Mohamed-Katerere, S.I. Karlsson, M.K.B. Lüdeke, G.D. Dabelko, F. Thomalla, I. de Soysa, M. Chenje, R. Filcak, L. Koshy, M. Long Martello, V. Mathur, A.R. Moreno, V. Narain, D. Sietz, D. Naser Al-Ajmi, K. Callister, T. De Oliveira, N. Fernandez, D. Gasper, S. Giada, A. Gorobets, H. Hilderink, R. Krishnan, A. Lopez, A. Nakyeyune, A. Ponce, S. Strasser, and S. Wonink., 2007. Chapter 7: Vulnerability of Human-Environment Systems: Challenges and Opportunities. Global Environment Outlook GEO-4, United Nations Environment Programme, Nairobi, Kenya, 301-360

Jain, H., Pankaj and Mick Moore, 2003. What makes Microcredit Programme Effective? Fashionable Fallacies and Workable Realities. IDS Working Paper 177, Institute of Development Studies, University of Sussex, Brighton. 
James, G., Witten, D., Hastie, T. and Tibshirani, R., 2015. An Introduction to Statistical Learning with Applications in R. Springer New York.

Kabir, M. E., Davey, P., Serrao-Neumann, S., and Hosain, M., 2018. Seasonal drought thresholds and internal migration for adaptation: lessons from Northern Bangladesh, In Hossians, M., Hales, R. and Sarker, T. (Editors), Pathway Towards Sustainable Economy: Bridging the Gaps Between COP21 commitments and 2030 targets of emission control, Springer, Cham. https://doi.org/10.1007/978-3-319-67702-6_10

Karim, A H M Z., 2014. Flood and Riverbank Erosion Displacees: Their Indigenous Survival Strategies in Two Coastal Villages in Bangladesh, Asian Social Sciences 10(4), ISSN 1911-2017 E-ISSN 1911-2025

Kartiki, K. (2011) Climate change and migration: a case study from rural Bangladesh. Gender and Development 19(1).

Khandker, S. R., 2012. Seasonality of income and poverty in Bangladesh. Journal of Development Economics 97(2), 244-256. Doi: 10.1016/j.jdeveco.2011.05.001

Klaiber, H. A., 2014. Migration and household adaptation to climate: A review of empirical research. Energy Economics. 46, 539-547.

Kleinbaum, D. G. and Klein, M. (2010). Logistic Regression A self-Learning Text. New York: Springer.

Kniveton, D., Schmidt-Verkerk, K., Smith, C. and Black, R., 2008. Climate Change and Migration: Improving Methodologies to Estimate Flows. Geneva: International Organization for Migration - Migration Research Series 33.

Martin, M., Siddiqui, T., Black, R., Billah, M., Abrar, C. and Kniveton, D., 2014. Climaterelated migration in rural Bangladesh: a behavioural model. Popul Environ 36, 85-110. DOI 10.1007/s11111-014-0207-2

McLeman, R. and Smit, B., 2006. Migration as an adaptation to climate change. Climate Change, 76, 31-53.

O'Loughlin, J., Witmer, F. D. W., Linke, A. M., Laing, A., Gettelman, A. and Dudhia, J., 2012. Climate variability and conflict risk in East Africa, 1990-2009. Proc Natl Acad Sci U S A 109(45):18344-18349.

Patnaik, U. and Narayanan, K., 2015. How effective are coping mechanisms in securing livelihoods against climatic aberrations?: Evidences from rural India, International Journal of Climate Change Strategies and Management 7(3), 359-374.

Piguet, 2011 The Migration/Climate Change Nexus: An Assessment. Paper presented in the International Conference on Rethinking Migration: Climate, Resource Conflicts and Migration in Europe, Retrieved May 2016 from www.network-migration.org

Piguet, E., Pécoud, A. and De Guchteneire, P., 2011. Introduction: migration and climate change. In Piguet, E., Pécoud, A. and De Guchteneire, P., Editors. Migration and Climate Change. Paris - Cambridge: Cambridge University Press - Editions de I'UNESCO

Piguet, E., Pécoud, A. and Guchteneire, P. D., 2010. Migration and Climate Change: an overview, COMPAS Working Papers (Centre on Migration, Policy and Society University of Oxford), (79)

Porter, J.R., L. Xie, A.J. Challinor, K. Cochrane, S.M. Howden, M.M. Iqbal, D.B. Lobell, and M.I. Travasso, 2014. Food security and food production systems. In: Climate Change 2014: Impacts, Adaptation, and Vulnerability. Part A: Global and Sectoral 
Aspects. Contribution of Working Group II to the Fifth Assessment Report of the Intergovernmental Panel on Climate Change [Field, C.B., V.R. Barros, D.J. Dokken, K.J. Mach, M.D. Mastrandrea, T.E. Bilir, M. Chatterjee, K.L. Ebi, Y.O. Estrada, R.C. Genova, B. Girma, E.S. Kissel, A.N. Levy, S. MacCracken, P.R. Mastrandrea, and L.L. White (eds.)]. Cambridge University Press, Cambridge, United Kingdom and New York, NY, USA, pp. 485-533.

Laczko, F. and Aghazarm, C., 2009. Migration, Environment and Climate Change: Assessing the Evidence, International Organization for Migration, Geneva, pp. 7-40. ISBN 978-92-9068-454-1

López-Carr, D. and \& Marter-Kenyon, J., 2015. Human adaptation: Manage climateinduced resettlement. Nature Comment. Retrieved on Sept 42015 from http://www.nature.com/news/human-adaptation-manage-climate-induced-resettlement1.16697

Lu, X., Wrathall, D. J., Sundsøy, P. R., Nadiruzzaman, Md., Wetter, E., Iqbal, A., Qureshi, T., Tatem, A., Canright, G., Engø-Monsen, K. and Bengtsson, L., 2016. Unveiling hidden migration and mobility patterns in climate stressed regions: $A$ longitudinal study of six million anonymous mobile phone users in Bangladesh. Global Environmental Change, 38, 1-7.

McLeman, R., 2014. Climate and Human Migration: Past Experiences, Future Challenges. New York: Cambridge University Press; New York.

Meeus, B., 2012. How to 'Catch' Floating Populations? Research and the Fixing of Migration in Space and Time, Ethnic and Racial Studies 35(10), 1775-93.

Mueller, V., Gray, C. and Kosec, K., 2014. Heat stress increases long-term human migration in rural Pakistan. Nat. Clim. Chang 4, 182-185.

Meyers, L. S., Gamst, G. C. and Guarino, A. J., 2013. Applied Multivariate Research: Design and Interpretation 2nd Edition. Sage Publications Inc, UK.

Myers, N., 2002. Environmental refugees: A growing phenomenon of the 21st century. Philosophical Transactions of The Royal Society B 357, 609-613.

Qin. H., 2010. Rural-to-urban labour migration, household livelihoods, and the rural environment in Chongqing municipality, Southwest China. Hum Ecol, 38(5): 675-690. Doi: 10.1007/s10745-010-9353-z

Revi, A., Satterthwaite, D.E., Aragón-Durand, F., Corfee-Morlot, J., Kiunsi, R. B. R., Pelling, M., Roberts, DCand Solecki W., 2014. Urban areas Climate Change 2014: Impacts, Adaptation, and Vulnerability. Part A: Global and Sectoral Aspects. Contribution of Working Group II to the Fifth Assessment Report of the Intergovernmental Panel on Climate Change ed CB Field et al. (Cambridge: Cambridge University Press) pp 535-612.

Rademacher-Schulz, C., Schraven, B. and Edward Salifu Mahama, 2014. Time matters: shifting seasonal migration in Northern Ghana in response to rainfall variability and food insecurity. Climate and Development 6(1), 46-52, http://dx.doi.org/10.1080/17565529.2013.830955

Riches, C.R., Harris, D., Johnson, D.E. and Hardy, B., 2008. Improving Agricultural Productivity in Rice-Based Systems of the High Barind Tract of Bangladesh. Los Baños (Philippines): International Rice Research Institute. 215 p. 


\section{ACCEPTED MANUSCRIP'}

Sami, F., Ali, F., Zaidi, S. H., Rehman, H., Ahmad, T., \& Siddiqui, M. I., 2009. The October 2005 earthquake in northern Pakistan: Patterns of injuries in victims brought to the emergency relief hospital, Doraha, Mansehra. Prehospital and Disaster Medicine 24(6), 535-539.

Scheffran, J., Marmer, E. and Sow, P., 2012. Migration as a contribution to resilience and innovation in climate adaptation: social networks and co-development in Northwest Africa, Applied Geography 33, 119-127.

Shahidur R., Khandker, M.A., Khalily, B. \& Samad, H. A., 2012. Seasonal Migration to Mitigate Income Seasonality: Evidence from Bangladesh, The Journal of Development Studies 48(8).

de Sherbinin, A, Levy, M., Adamo, S., MacManus, K., Yetman, G., Mara, V., Razafindrazay, L., Goodrich, B., Srebotnjak, T. and Aichele, C., 2012. Migration and risk: net migration in marginal ecosystems and hazardous areas. Environmental Research Letters 7. doi:10.1088/1748-9326/7/4/045602

Shardul, A. and Maëlis Carraro, 2010. Assessing the role of microfinance in fostering adaptation to climate change, OECD Environmental Working Paper No. 15, 2010, OECD publishing, OECD. doi: 10.1787/5kmlcz34fg9v-en

Smith, S. and McCarty, C., 2009.Fleeing the storm(s): An examination of evacuation behaviour during Florida's 2004 hurricane season. Demography 46, 127-145.

Stern, N.H., 2007. The Economics of Climate Change: The Stern Review, Cambridge University press.

Suppasri, A., Goto, K., Muhari, A., Ranasinghe, P., Riyaz, M., Affan, M., Mas, E., Yasuda, M. and Imamura, F., 2015. A Decade After the 2004 Indian Ocean Tsunami: The Progress in Disaster Preparedness and Future Challenges in Indonesia, Sri Lanka, Thailand and the Maldives. Pure and Applied Geophysics 172 (12), 3313-3341.

Stojanov, R., Kelman, I., Ullah, A K M A, Duží, B., Procházka, D. and Blah `utová, K K., 2017. Local Expert Perceptions of Migration as a Climate Change Adaptation in Bangladesh, Sustainability 8:1223. doi:10.3390/su8121223

Tacoli, C., 2009. Crisis or adaptation? Migration and climate change in a context of high mobility. Environment and Urbanization, 21, 513-525. https://doi.org/10.1177/0956247809342182

United Nations, 1998. Recommendations on Statistics of International Migration. New York: United Nations.

Warner, K., Enrhart, C., de Sherbinin, A., Adamo, S. and Chai-Onn, T., 2009. In Search of Shelter: Mapping the Effects of Climate Change on Human Migration and Displacement (Bonn: United Nations University, CARE, and CIESIN-Columbia University.

Waters, M. C., 2016. Life after Hurricane Katrina: The Resilience in Survivors of Katrina (RISK) Project. Sociological Forum, DOI: 10.1111/socf.12271

Warner, K., 2010. Global environmental change and migration: governance challenges, Global Environmental Change 20(3), 402-413. 


\section{Highlights}

- Association between hazard and temporal aspect of human mobility is explored

- Demographic and economic vulnerability are linked with internal migration

- Both the hazard context and socio-economic factor influence migration

- Policy interventions for different groups of internal migrants is necessary 


\section{Author's Accepted Manuscript}

Drivers and temporality of internal migration in the context of slow-onset natural hazards: insights from north-west rural Bangladesh

Mohammad Ehsanul Kabir, Silvia SerraoNeumann, Peter Davey, Moazzem Hossain, Touhidul Alam

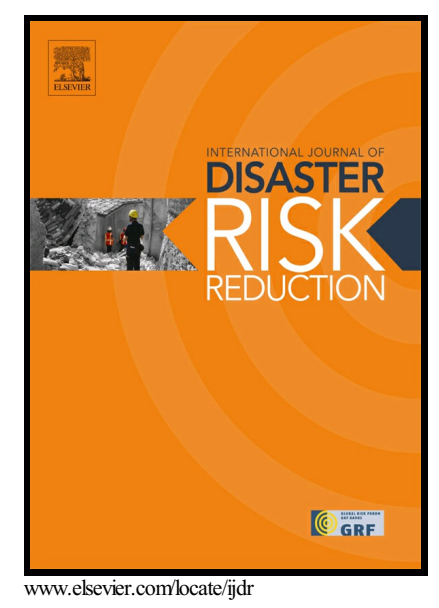

PII: S2212-4209(18)30076-1

DOI: $\quad$ https://doi.org/10.1016/j.ijdrr.2018.06.010

Reference: IJDRR923

To appear in: International Journal of Disaster Risk Reduction

Received date: 18 January 2018

Revised date: 3 May 2018

Accepted date: 21 June 2018

Cite this article as: Mohammad Ehsanul Kabir, Silvia Serrao-Neumann, Peter Davey, Moazzem Hossain and Touhidul Alam, Drivers and temporality of internal migration in the context of slow-onset natural hazards: insights from north-west rural Bangladesh, International Journal of Disaster Risk Reduction, https://doi.org/10.1016/j.ijdrr.2018.06.010

This is a PDF file of an unedited manuscript that has been accepted for publication. As a service to our customers we are providing this early version of the manuscript. The manuscript will undergo copyediting, typesetting, and review of the resulting galley proof before it is published in its final citable form. Please note that during the production process errors may be discovered which could affect the content, and all legal disclaimers that apply to the journal pertain. 